\title{
Design Reciclado Project
}

\author{
Glaucinei Corrêa $^{1, a}$, Karine Moura ${ }^{2}$ and Arthur Souza ${ }^{3}$ \\ ${ }^{1}$ Universidade Federal de Minas Gerais, Depto TAU, Rua Paraíba, 697 - Funcionários - 30.130-140 - Belo Horizonte/MG - Brasil \\ ${ }^{2,3}$ Universidade Federal de Minas Gerais, students, Rua Paraíba, 697 - Funcionários - 30.130-140 - Belo Horizonte/MG - Brasil
}

\begin{abstract}
|Abstract. This article presents the "Design Reciclado" Project, which has as main objective promoting the social-economic inclusion of waste pickers from the ASMARE - "Associação dos Catadores de Papel, Papelão e Material Reaproveitável de Belo Horizonte" - association. The project was based on the development of products and other design actions by the waste pickers, that had to use an ecological and sustainable appeal. The items would be produced and commercialized by the association to promote an alternative income source for the waste pickers involved in the Project. The methodological procedures used included an active participation of undergraduate scholarship students, ASMARE's waste pickers and other guest contributors on the conception, cooperation and integration of methods and instruments during the execution of the project. Dialogic relations based on proximity between the subjects, respect and mutual recognizing guided the activities. The steps of development of the project were: (1) Preparing the students for the community work and (2) Researching and studying groups and institutions from all over the world that do this type of work; (3) Preparing didactic material to be used on the workshops; (4) qualification of the waste pickers for the development of the products; (5) development of the products, brands and packaging together with the collectors; (6) disclosing of obtained results with the program. From the outcomes, it is possible to conclude that the project achieved most of its goals, despite the difficulties and changes that happened over the development of the activities. Also, the development of the project activities allowed the integration between society and university, promoting academic learning for the students.
\end{abstract}

Keywords. design, garbage collectors, recycling, sustainable development.

\section{Introduction}

The Association of Paper, Cardboard and Reusable Material collectors of Belo Horizonte - Associação dos Catadores de Papel, Papelão e Material Reaproveitável de Belo Horizonte (ASMARE), was founded in 1990 and emerged from the mobilization and training of the collectors by a catholic institution, known for taking care of homeless people. "Pastoral de Rua", a project from Belo Horizonte's archdiocese, is the result of an intensive process of mobilization. Nowadays, it takes cares of 180 associates and former homeless.

The Project Design Reciclado, main subject of this article, is part of CASOS: catadores de sonhos, a extension program which develops a partnership between the architecture school of UFMG - Escola de Arquitetura da Universidade Federal de Minas Gerais (EAUFMG), with the Design Course of UFMG and the ASMARE association.

The Project started from ASMARE's demand, to have their own products, developed with recyclable materials collected by their members, especially the ones with lower commercial value for the association, such as, wood. In that way, they could produce, commercialize and have an alternative income source to the garbage collection. This could give more autonomy and better living conditions for the ones involved with the activities of the association.

Another objective of this project is to promote the integration between society and academy through actions linked to it, and thus, improving the intellectual and social formation of the scholarship students involved by showing the reality and history of the waste picker's lives.

According to Bonsiepe (2010, p 71-72), there is six "postures" on the Design-Art relation that show up in its pure form or mixed: 1) The conservative focusing, in which the artisan is protected from external design influences; 2) the aesthetic focusing in which the artisans represent the popular culture and take its crafts to a popular art level; 3) Productivity focusing, where artisans are considered cheap and qualified human resources for design prototypes manufacturing; 4) Cultural focusing, in which the local projects from artisans are considered the starting point for the truly latin-american design; 5) Paternalism focusing, where the artisans are firstly considered political consumers of assistance politics and serve as mediators between products and commercialization; 6) Innovation promotion focusing, in which states the artisan's

a Corresponding author: glaucinei@ufmg.br 
autonomy to improve his subsistence conditions.

In this Project, the last type of Bonsiepe's focusing was aimed, which means the main objective was to make the associates autonomous to the product development activities, so, with time, they could not rely on the University actions anymore.

For this reason, the Action-Research was used as focus for the planning and construction of part of the acts. From Thiollent (1986), it is a social research with empirical basis, that is designed and realized with a strict association with an action or the solving of a problem in common and in which the researchers and participants are involved in a cooperative or participative manner. Thus, the axis of articulation of the project's actions was on the contribution design for this new economic proposal: solidarity economy.

According to Arruda (2003), the concepts and strategies which cover the solidarity economy are: a) Ethical consumption: as a sustainable response to human needs; b) Self-managed production: workers with property rights; c) Collective management in which the company is conceived as a community: fair trade, cooperative credit, cooperative education and dialogic communication (own translation) (ARRUDA, 2003, p. 30).

Therefore, the proposal of Design Reciclado Project was to unite the two parts: the demands of ASMARE placed among other organizations which are seeking new formats based on solidarity economy - and Design; which is an area that have to attend to a series of factors relating to necessity of users and market, which means responding to social, economic, productive, environmental, symbolic, cultural, among with other aspects (CORRÊA e CASTRO, 2013).

In this sense, the activities of the project worked in harmony with solidarity economy, the Pedagogic Project of the Design Course and the Development Planning of UFMG.

\section{Theoretical Fundamenting}

The relation used in the project activities was based on the proximity of subjects, a dialogic relation relied on mutual recognizing and respect. Researchers, professors, students, artisans and members of the community exchanged knowledge and discovering. The project breaker the common relation in which the teacher/master is the only one responsible for teaching and the student for learning. It became a multilateral learning process.

In this project, the learning concept of Lave and Packer (2008) was used. This means that everyone is in a constant learning process, independently of the location for that to occur.

According to Lave and Wenger (1991), when learning is discussed, there is always a common thought of a Master-student relation. When putted in a practical situation, the professor's action becomes surprisingly variable in time and space. This relation is not a fixed characteristic of the learning process.

From that principle, looking to describe how the design intervention happened - in the product development, professional training and workshops fragments of texts from authors that studied the design influence on popular art were used. Although crafts are not the specific case of this Project, in some cases the development of products was similar to them. Besides that, there is closeness in this kind of development, which involves groups of people, with the crafts work. In general, these references were important for the development of the activities of this Project.

Nemer (2003) discussed the matter of listening the artisan: "The craftwork is the result of the human hand and the keeper of its complex culture. It is important to get to know the embroiderer artisan and listen to her, creating paths to emerge what she considers an icon. She is the creator and the only one who can interpret her work. She does not need to make table mat sets with the main monuments of her city. [...] The correct intervention consists in, many times, helping her to perfect what she does, but always respecting its essence." (own translation).

Borges (2006) stated about the respect that needs to exist on the moment of the intervention: "When we do not respect the artisan, I'm convinced that it is better to leave it alone than intervene without caution, with pretension. The hazardous potential of a badly concluded intervention is high and its effects are very harmful." (own translation).

Barroso (1999), questions the product's mischaracterization: "How can we intervene in the product and in the craft process without misrepresenting it, valuing and reinforcing the regional traditions, the craftsmanship and the existent relationships inside the groups in focus?" (own translation).

These citations reflect the great importance attributed to the activities carried out in this Project. We believe that the respect and the cultural valorization of the groups/institutions involved, in this case, ASMARE, should serve as basis for all the project's development. If the work was done in a different manner, the results could be incomplete and compromised.

The goal was to make the involved garbage collectors realize that values could be incorporated in their products in the process of creation and development. For this reason, it was fundamental to consider the experimentation, the testing and how to do them.

\section{Methodological procedures}

The methodological procedures used were guided by the active participation of the ASMARE associates, the scholarship holder students and the guest contributors in actions, which involved the whole project. In this sense, the steps developed over the project were:

(1) Training of the students for the work with the community: to deal with this target audience people who are normally excluded from society in some way - it was necessary, first, to provide a training that would help to clarify the ways to deal with this group. Thus, this first step aimed to prepare the students, through meetings with administrative technicians of ASMARE, to 
elucidate who are these people, the possible problems that they would face, and, especially, the ways to deal with this situation.

(2) Research of the groups and institutions in Brazil and worldwide which execute this kind of activity: this step of the Project had as goal to research the state of art concerning associations and other kinds of organizations, which develop work like that of ASMARE. In other words, governmental organizations or the nongovernmental ones which develop projects that focus on recycling, craft production and/or the involvement of the design with the craft production in order to allow the exchange of experiences among students, teachers and institutions.

In this two first steps, while we were researching the subject, we also had weekly meetings in order to discuss the articles researched selected which addressed topics related to the activities we were dealing with. Every week one of the scholarship holder students was responsible for the presentation that should have: a) Presentation of the summary and structure of the article; b) Author's biography; c) Main parts of the article relevant to the discussion; d) Critical reflection related to the Project; e) Showing the references used in the article.

This practice made the week meetings more dynamic and allowed every participant to enlarge their knowledge about the authors and the subjects researched.

(3) Preparation of the didactic material for the Project: the students prepared material for the training of ASMARE's associates. It contained themes that helped to a better understanding of the project's operation and were previously defined with the association's board: concepts related to design, crafts and Market; creativity and development of products; behavioral trends and product lines; study of color and form; properties and processes of materials; packing. The methodological resources included lectures, as well as practical classes.

(4) Qualification of ASMARE's associates for the development of the products: this step included the preparation of the waste pickers, involved in the Project, so they could be aware of the development of the products, being able to actively contribute and participate in the whole process. The students were responsible for the training and the meetings with the associates happened weekly, to enable the ones who are part of the Project to develop the products, being ASMARE responsible for indicating the associates who would participate in the Project.

Unfortunately, this step was not concluded. After the third workshop, it was necessary interrupt the process. The reasons will be elucidated later in this article.

(5) Development of the products, brands and packaging together with the collectors/associates: this step includes all the development of the products. Thus, the students could experiment and put into practice what they learned in the classroom. Besides that, they were committed to involve the associates in the development of the products.

The product development process was constituted of four phases: research, analytical, generative and executive. In the RESEARCH phase, the students made bibliographic researches on crafts, creative economy, creation methods, group dynamics, possible users of the products and similar projects as well. Still in this phase, they conducted a market analysis to collect information about the interest on sustainable products.

The ANALYTICAL phase comprises specific researches, survey of similar and related products, translation of the values into requirements and definition of the project specifications (also called briefing).

The GENERATIVE phase involved the generation of alternatives, by means of drawings, models and mockups, study of object sizing, elaboration of technical requirements and production techniques. Furthermore, in this phase, the packaging, brands and names of the products were developed/designed.

It became necessary to review what was being developed/created all the time, to check if the products were following the specifications and if it would be feasible to be produced by the collectors.

Apart from the responsibilities of each scholarship student, everyone participated actively in this phase. Weekly meetings were made to evaluate the progress of the projects and to review and redo models and mockups.

In the EXECUTIVE phase, the students built the prototypes for trials and developed specifications for the products. Still in this phase, because of the results, it was necessary to review some of the solutions of the projects, and change few details to improve the products and facilitate the production as well. Besides that, the students elaborated all the technical documentation to manufacture the products.

(6) Disclosure of results (processes and products developed) achieved with the program: this last phase, in progress, consists in the elaboration of articles, preparation of the final event/exhibition, the elaboration of a book, in which all the process, methodology adopted, and also the results reached in the project will be disclosed.

\section{Challenges in project execution}

During the development of this project, an open and dialogic relationship among those ones involved in it was aimed: the coordinators of the project, the scholarship students, and the waste pickers/associates of ASMARE - which were, frequently, represented by the board of directors - to search for joint solutions to reach the goals of the project.

Even though, during the execution of the Project, several problems were faced, which somehow affected the compliance with the initial objectives. All the problems were treated as openly as possible, always trying to avoid harming the main activities of the association: collection, sorting and commercialization of materials.

The problems were important to the growth of the involved, as they had to rethink alternative ways to the ones previously planned, allowing the increase of experience in solving adversities.

The main problems (which became challenges) are listed below, the alternatives conjectured to solve them, 
as well as the outcome of the actions.

\subsection{The beginning of the Project and the new reality of ASMARE}

Right at the start of the Project, in January of 2015, it came to knowledge that the municipality of Belo Horizonte, from that moment onwards, would suspend the monthly budget that was passed to ASMARE, corresponding to $\mathrm{R} \$ 61,000.00$, at that time. This fund was used to: a) pay the technicians who worked in the administration; b) pay the transport tickets for the collectors/associates; c) carpentry and handicraft workshop maintenance; d) maintenance of trucks used to collect materials.

The municipality's abandoning relates to Bonsiepe's (2013, p. 63) argumentation about the erosion of public spaces on the last decades: "[...] One can verify the emptying of the democracy concept with the fulfilling of private interests, increasing the atrophy of social interests. This process motivated the appearing of voices that claim for a reinvention of the democratic domain as a democratic space, aiming for a truly recovery of the democracy."

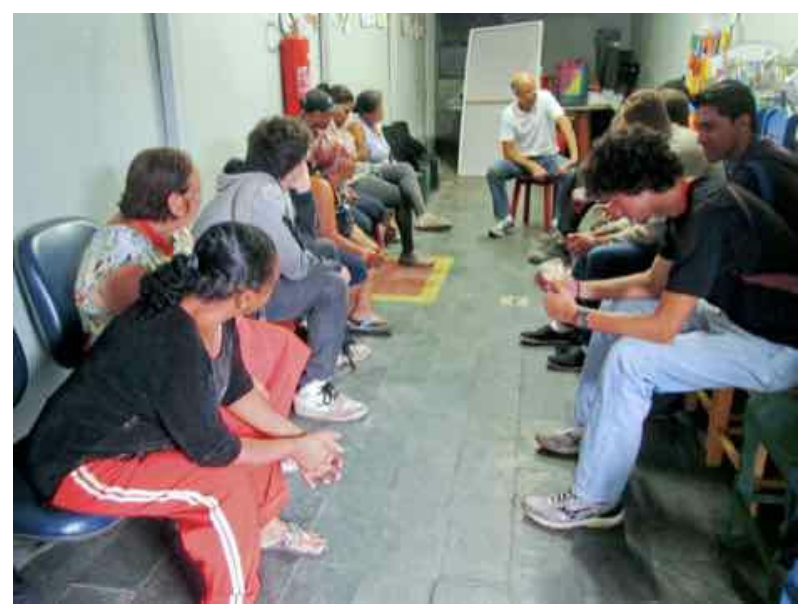

Figure 1. First meeting with the collectors.

With the suspension of the budget, technicians were dismissed and the associates had to deal with selfmanagement and at the same time, keep the association working, in other words, continue the collection, sorting and commercialization of the recyclable materials.

Despite all the difficulties, we decided to start the activities because we believed that, somehow, the Design Reciclado Project could contribute to enabling the members to rebuild again benefiting from the results of it. Furthermore, there was a commitment to comply with a schedule previously approved with the development institution (MEC/SESu) of this project.

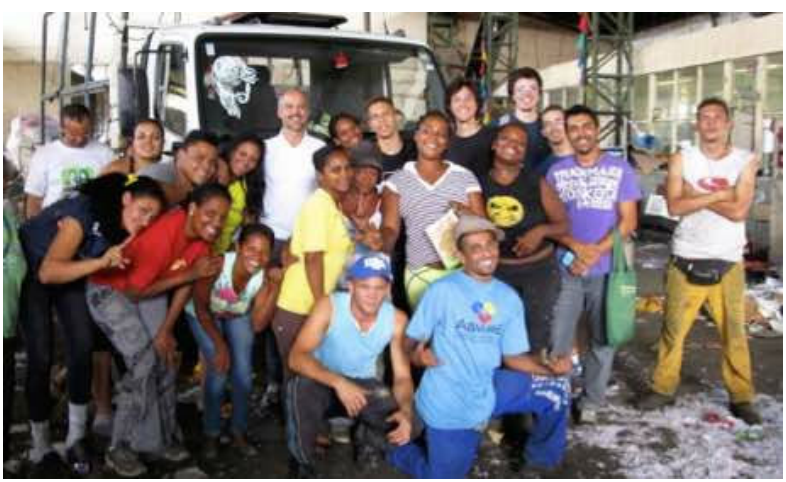

Figure 2. Second meeting with the collectors.

\subsection{Changes in the direction of the Project}

To increase the participation of waste pickers in the workshops, an attempt to encourage them was made, setting up meetings scheduled by them, snack-meetings to explain and to better detail the Project and how their participation would be in the activities, and some meetings with the board of directors. There were many frustrated attempts, thus, after the third workshop, we realized that it was not possible to insist anymore, since the adherence of collectors to the Project was very low. Therefore, we decided, in June of 2015, in common agreement with the board of directors, to review the Project's actions, to continue to meet the demand of ASMARE without departing from the main objectives of the Project.

The alternatives found to change the procedures of the project were: a) to act in the development of exclusive products (gifts) of ASMARE, even though the training process of the collectors/associates was not finished, and b) creation and development of a website for the association.

Regarding the development of the products, it was decided, together with the board of ASMARE, that the collectors would participate in all the phases, by means of meetings, to present the progress of the projects, and the training process would happen in the production phase of the products, to facilitate the collectors' engagement, once this activity was more objective and results were more evident to the participants.

The development proposal for a website was a request of the collectors/associates themselves, with the main aims of disclosing the activities of the association, easing the donation and commercialization of the materials, and besides that, present the history and importance of ASMARE to the society.

\section{Development: products and website}

In the research phase a big demand coming from companies was noticed: linking on to their corporate identities the values of sustainability. The tableware used in the office and decoration objects were the ones that showed the most interest of stores, companies and people researched.

Therefore, three products were defined to be developed: a toy/game, a commemorative present to 
ASMARE and a corporate gift.

The solution for the game was to create multiple ones in one product. There are 16 cubes, and in each one of its faces, there is one different game. They are made of pinewood (which comes from the pallets donated).
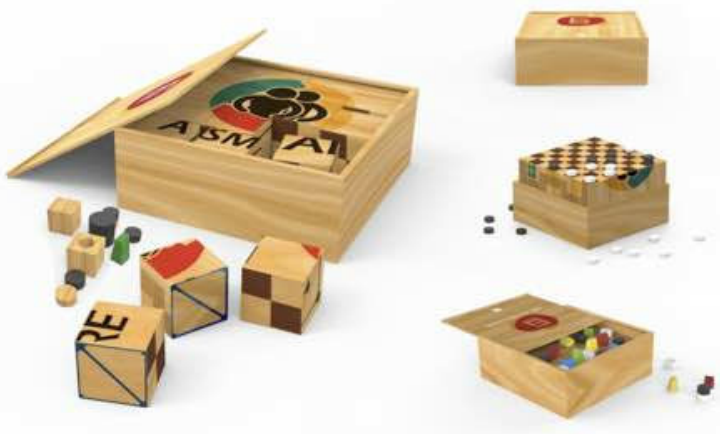

Figure 3. Toy/game.

The games are printed on the wood using silkscreen. Hereafter, the images of the games (Figure 4).
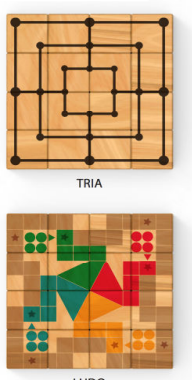
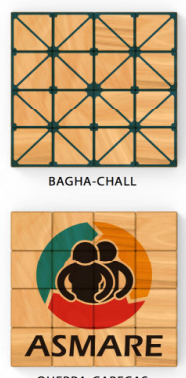
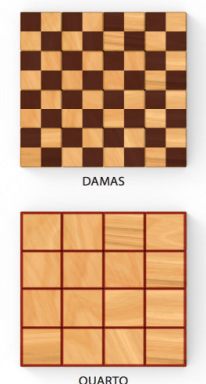

Figure 4. Illustration of each one of the six games.

The commemorative gift to ASMARE, should be directed to the association's partners: companies which offer support to their employees. And should add a symbolic value to the collector's cart that represented the image of the association.

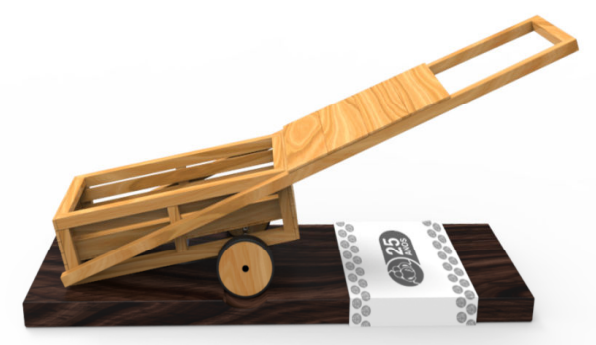

Figure 5. Illustration (render) of the commemorative gift.

The solution found was to make a cart in a smaller scale, so it could be used as a table object holder. It is also manufactured with Pinus wood.

For the corporate gift, the solution was an object holder whose pieces could be used together or separately. The pieces fit together to reduce the occupancy space on the table, as well as to diminish the volume in the transportation and storage of the product.

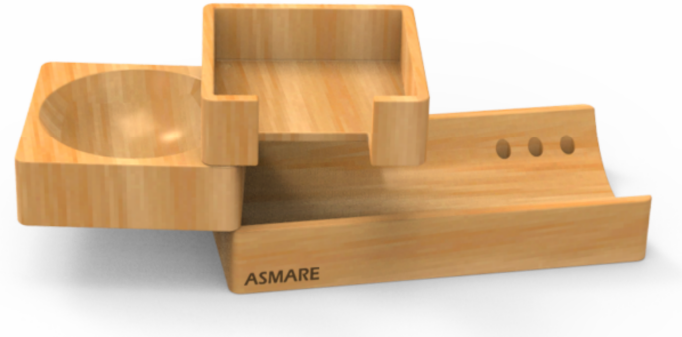

Figure 6. Corporative gift.

For the ASMARE website, the requirements were: a) it should have a Web page with the history of the association, a timeline showing how it started and the social focus it has been exerting; b) some space dedicated exclusively to companies (large generators), presenting the ASMARE service as a solution to the "problems" related to waste, showing its importance for reverse logistics; c) some space to testimonials from garbage collectors who left the street thanks to ASMARE; d) some space for information about recycling, specifying the benefits of the collectors/associates work to the society, showing statistics related to the activities and results of the association.

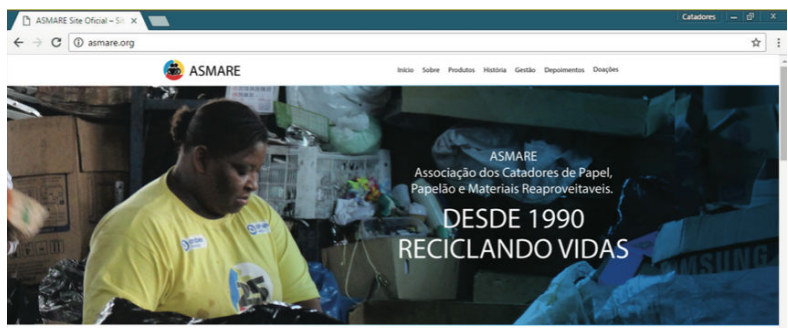

Importancia do trabalho social da ASMARE.

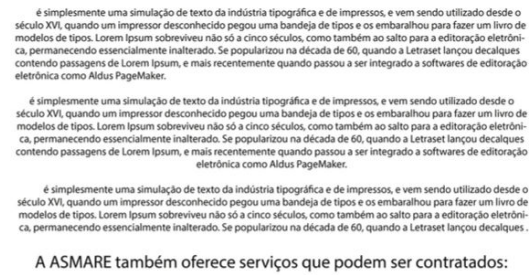

Figure 7. Image of part of ASMARE's website.

\section{Final considerations}

In summary, it can be concluded that the Project reached most part of its goals, despite all the difficulties faced and the changes that occurred during the development of activities.

The scholarship students involved with the project received training so they could perform in this kind of action. This articulation created not only a sociotechnical impact, but also personal and social ones, in the qualification of the students, the generation of knowledge and the dialogic relationship with the society. This happened because the students put into practice what they have learned in the university, through the 
direct contact with the external audience.

When we analyze everything that was done during the Project - the training of the students; comprehension of the association and the relation with the collectors; preparation of the workshops; development of the products - it can be noticed that, we could, through Design, contribute, somehow to the improvement of life quality of the collectors, with the amelioration of the association, and also to contribute with the qualification of the students.

On the other hand, many difficulties were faced on the manufacturing and disclosure of the products and especially on turning the collectors into autonomous.

From that, some aspects can be studied relating to how Design can be used in the kind of institutes as the one of this project.

First, it is necessary to understand the institution in its context, which means all the complexity of its activities and in which part of the market it acts. With ASMARE, the peculiarity is on the way of acting, which values homeless people and ex-prisoners more than commercial aspects.

Another important aspect it the understanding of the complexity of the activities and actions involved in the project. Design does not have the ability to solve every problem that appears, therefore, a multidisciplinar team is necessary to face the challenges that appear and can not be solved by designers only.

The low self-esteem, lack of security and confidence of the people involved, in this case the associates and garbage collectors, was the main difficulty for the development of the project. In that sense, every project that needs to deal with communities must take into account those aspects and how to deal with them.

Finally, it is possible to conclude that turning a community or institution into an autonomous one needs time. It is necessary to invest in resources and to think about long-term works. Activities realized in few years can bring improvement in certain way, but creating autonomy needs even more time. For that reason, this project will continue for the following years.

To sum up, a relevant aspect to be taken into account is that, although we did not fully achieved all the goals of the project, the ones we concluded made a difference on the daily life of the collectors/associates. It could be noticed an improvement in their self-esteem.

\section{Acknowledgments}

We would like to thank MEC/SESu, for the financial assistance to the Project.

A special thanks to the Pró-reitoria de Extensão (PROEX) of the Universidade Federal de Minas Gerais (UFMG), for the support and incentive during all the process of development of the Project.

\section{References}

ARRUDA, Marcos. Situando a economia solidária. In: Economia Solidária: desafios para um novo tempo.
Fundação Luís Eduardo Magalhães. Salvador: FLEM, 2003. 132p (Cadernos FLEM, 5), p. 1932.

BARROSO NETO, Eduardo. Design, Identidade, Cultura e Artesanato. Primeira Jornada Iberoamericana de Design no Artesanato, 1999.

BONSIEPE, Gui. Identidade e contra-identidade do design. Barbacena: Ed.UEMG/Cadernos de Estudos Avançados em Design - Identidade, p. 63-75, 2010.

BONSIEPE, Gui. Tendências e antitendências no design. Barbacena: Ed.UEMG/Cadernos de Estudos Avançados em Design - Humanismo, p. 61-69, 2013.

BORGES, Adélia. A intervenção do design no produto de artesanato. In: Seminário Artesanato: intervenções e mercados (caminhos possíveis). Centro de Negócios de São Paulo, 25 de outubro de 2006. São Paulo: Artesanato Solidário/Artesol e SEBRAE, 2006.

CORRÊA, Glaucinei Rodrigues; CASTRO, Maria Luiza A. C. O pensamento complexo de Edgar Morin e o design. Revista Estudos em Design (online). Rio de Janeiro, v 21, n 1, p 115, 2013.

LAVE, Jean; PACKER, Martin. Towards a social ontology of learning. In: NIELSEN, K. et al. A qualitative stance: essays in honor of steinar Kvale. Oxford: Aarhus Universitetsforlag, 2008.

LAVE, Jean; WENGER; Etienne. Situated learning: legitimate peripheral participation. New York: Cambridge University Press, 1991.

NEMER, J. A. Palestra no VII Encontro Design e Artesanato do Museu A CASA. In: A Casa: museu do objeto brasileiro, 2003.

(http://www.acasa.org.br/ensaio.php?id=46\&modo=pain el)

THIOLLENT, Michel. Metodologia da Pesquisa-Ação. São Paulo: Cortez, 1986. 